\title{
Identifying the effect of emotions in government-citizen online (G2C) tourism based on the HEART metrics
}

\author{
Tri Lathif Mardi Suryanto ${ }^{a^{*}}$, Akhmad Fauzi ${ }^{a}$ and Djoko Budiyanto Setyohadi ${ }^{b}$
}

${ }^{a}$ Universitas Pembangunan Nasional Veteran Jawa Timur, Surabaya, Indonesia

${ }^{b}$ Universitas Atma Jaya Yogyakarta, Yogyakarta, Indonesia

\section{H R O N I C L E A B S T R A C T}

Article history:

Received: March 14, 2021

Received in revised format: June

25, 2021

Accepted: July 30, 2021

Available online: August 3, 2021

Keywords:

Emotion

G2C

e-Government

HEART Matrices

Intention to Reuse

\begin{abstract}
Emotional factors in the use of technology have the potential to be studied, since the important role of user engagement in the information technology development cycle, emotional plays a role in influencing the relationship between consumers and service providers. Previous research has examined various emotional factors of a person in operating digital services through online sites, but it is necessary to find an empirical correlation between emotional variables and one's intention to reuse (IR) online services. This study aims to determine whether users' emotions affect their decision to reuse Government to Citizen (G2C) online tourism services in Indonesia through the HEART Metrics approach. Furthermore, this quantitative study distributed questionnaires using simple random sampling to respondents who had used online tourism. Then analyse 260 research data using the SEMPLS method by running Warp-PLS 5.0. The findings of this study are among the 5 HEART Metrics factors, 3 of which affect IR, namely Engagement, Retention, and Task Success, while Happiness and Adoption empirically have no significant effect on IR. Our results show that to gain consumer engagement with online services, service providers must consider the emotional elements of the users so that service reuse goals can be achieved. Furthermore, this research can be considered as an alternative recommendation for online tourism service providers, as well as the findings of a new model proposed to contribute to similar research in the future.
\end{abstract}

(C) 2021 by the authors; licensee Growing Science, Canada.

\section{Introduction}

Government policy to keep tourism destinations open in Covid-19 Pandemic situation causing topics among the general public. Government via Ministry of Tourism and Creative Economy (Kemenparekraf) still doing their job to give tourism services for domestic and international tourist, this is seen with actively www.indonesia.travel website that gives digital information services for incoming tourist (The Official Website of Indonesia Tourism - Indonesia Travel, 2021). With slogan "Wonderful Indonesia", digital information services expected to draw many visitors who looking for tourism destination info via official website www.indonesia.travel which managed by Government under Kemenparekraf. Admittedly, tourism is one of sectors that have the most potential to increase National in-come (Natalia et al., 2019). With rapid growth of technology and massively social media usage, Kemenparekraf developed www.indonesia.travel as an information system for a communication place between Government and public (G2C), also an effort to promote popular tourism destinations in Indonesia. Many digital information regarding tourism that still active in the middle of Pandemic, proof that Indonesian tourism still is an interesting thing to do, along with related research (Natalia et al., 2019; Nugraha \& Sudirman, 2019; Rudenko \& Tedjakusuma, 2018; Yunus et al., 2018). Previous researchers have found that tourism services in Indonesia in digital form make tourism a place

* Corresponding author.

E-mail address: trilathif.si@upnjatim.ac.id (T. L. M. Suryanto)

(C) 2021 by the authors; licensee Growing Science, Canada. doi: $10.5267 /$ j.ijdns.2021.8.003 
in the modernization of information as well as being able to influence the existence of tourism shown. Thus, the Government's efforts through the Ministry of Tourism and Creative Economy to continue to strengthen tourism in Indonesia with technological modernization needs to be appreciated in the form of participating in continuing related research. Yet, on pre-research, we found that the young are not or not yet able to access the official website of www.indonesia.travel as their references on tourism, instead, they find Indonesian tourisms via social media that they use. Surely this is a phenomenon that can be only limitedly and thoroughly observed in the user experience aspect. What are the factors which affect those conditions and why are the young reluctant to use digital information service from the Kemenparekraf. A service connection really depends on user experience, the real problem that Kemenparekraf faces through website-based tourism information suggesting the research of user experience to use Google HEART Metrics method which was developed to get the explanation why someone uses www.indonesia.travel. According to (Hung \& Parsons, 2017; Lalmas et al., 2014) every digital service / service as far as possible a measurement of its attachment, HEART Metrics is a framework to start an investigation of user experience (Rodden et al., 2010), with indication that user experience is not yet as expected as user want, can be measured with user experience measurement tool (Albert et al., 2008). Aside from HEART Metrics, some methods developed by previous research, measurements tools for user experience (Finstad, 2010), 10 Usability Heuristics for User Interface Design (10 Usability Heuristics for User Interface Design, 2021), HaTS (Müller \& Sedley, 2014), and various user experience evaluation methods. HEART Metrics is not focused on a certain measurement tool, but on the whole framework from the program that will be tested (Illias \& Kokkinaki, 2015). So, HEART Metrics method is considered suitable to test user experience as a benchmark of how people willingly use www.indonesia.travel.

\section{Literature review and theoretical framework}

\subsection{Government to citizen (G2C)}

Basically, G2C terminology is built for electronic commerce carried out between the Government and its citizens or consumers, including paying taxes, registering vehicles, providing information and services in a digital way. In Indonesia, G2C services have been implemented in various fields such as tax payments https://djponline.pajak.go.id/, copyright management https://www.dgip.go.id/, driving license processing http://sim.korlantas.polri.go.id/, to those who are going to https://www.indonesia.travel/ and many others. Various researchers have taken a role in capturing the performance results of G2C tourism, showing the quality of information is directly proportional to the quality of the website to be able to affect satisfaction so that consumers decide to visit the destination (Nugraha \& Sudirman, 2019), while the perception of convenience has a significant effect on perceptions of usefulness in operation of online tourism (Natalia et al., 2019).

\subsection{HEART metrics (UXQ)}

HEART Metrics approach which is empowered by Google Researchers (Rodden et al., 2010). EART Metrics have 5 variables that describe user Experience Quality (UXQ), such as Happiness, Engagement, Adoption, Retention, and Task Success. Starting from the findings of Rodden (2010), leading to research which was followed up by previous research, (Boy et al., 2015) HEART became a web analytic parameter which was then added to visualization of exploratory information with narrative visualization and storytelling to help engage users in exploration, (Lachner et al., 2017) Adapting UX metrics based on the HEART framework to establish direct communication with users, and (Conlen et al., 2019) The HEART framework for measuring user experience of web applications is not fully applicable to studying interactive articles. As stated (Illias \& Kokkinaki, 2015) that HEART Metrics is not focused on certain measurements but on the whole structure of program that is about to be tested, therefore, it is very likely if the HEART Metrics become a whole framework for seeing general illustration of UQX that has influence on something, so in this paper, HEART Metrics is an independent variable that on hypothesis showed as positive, can affect Intention of Reuse (IR).

\subsection{Intention to reuse (IR)}

Issues related to repurchase or repurchase intentions have been raised by (DeLone \& McLean, 2004, 2003) from which an Information System Success Model theory (ISSM) framework has been compiled. research in the field of human computer interaction (HCI), such as (Hsu et al., 2014) IR is influenced by satisfaction with websites, satisfaction with sellers, and perceptions of website quality, (Suryanto et al., 2016, 2017) in the case of service implementation. campus digital, IR is influenced by system quality and information quality, (Lee \& Kim, 2018) in the case of the Tourism Information app in China, IR is influenced by customer satisfaction, (Park, 2019) in the case of airline digital services, customer satisfaction and inflight experience customers determine overall customer satisfaction and IR, and (Min Tun, 2020) pin the case of mobile banking, IR of mobile banking services is significantly influenced by $\mathrm{p}$ social influence, user satisfaction, and perceived efficacy.

In cases that have been observed by previous research, it is very possible when related research develops IR variables that are influenced by emotional technology, in this study a framework is formulated that proposes a measurement of emotion in the use of technology represented by variables from the HEART framework, namely Happiness, Engagement, Adoption, Retention, Task Success which are hypothesized to influence Intention Reuse. 


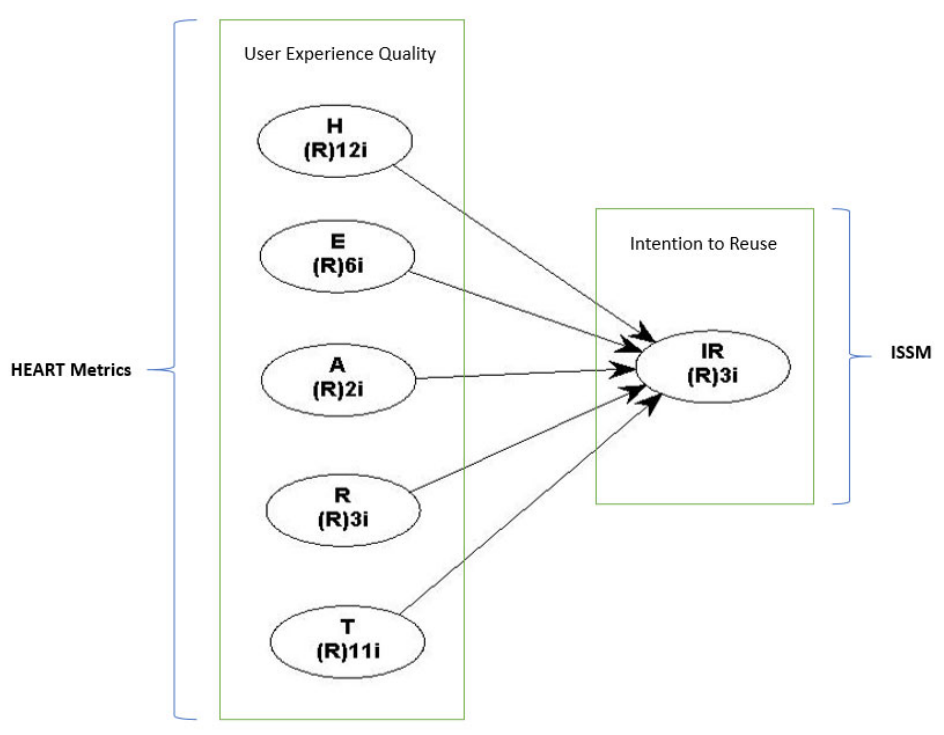

Fig. 1. Research Model Hypothesis

\section{Research Methodology}

This research uses Structural Equation Modelling (SEM) based on Variance-Based, Component/Variance-Based Structural Equation Modelling is often called Partial Least Square (PLS). This method is used to carry out causal-predictive analysis of a hypothetical finding, various procedures must be carried out to meet SEM assumptions both in the data collection process and in data processing through Warp-PLS 5. This paper is using a quantitative research method and propped up with qualitative data (Hameed, 2017; Müller et al., 2014). This research using amount of population by 452.626 users that know www.indonesia.travel and using sample data of 260 respondents who have ever accessed to www.indonesia.travel, also the sample selecting technique that has been used is simple random sampling (Müller et al., 2014) and added with respondent characteristic that has ever accessed the website www.indonesia.travel. The qualitative data is gathered by doing interviews with people that are actively related in Indonesian tourism services such as tour guides and travel \& tourism agency services. After getting data from the questionnaire, the data was processed using SEM-PLS with Path Analysis approach (Kock, 2014, 2013).

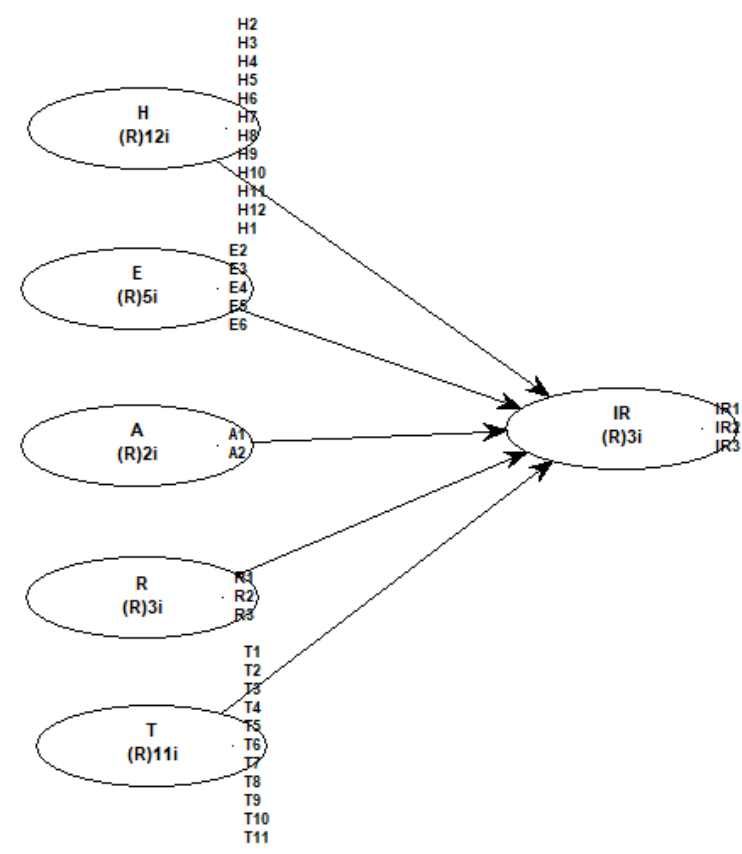

Fig. 2. Experiment Variable Model Hypothesis 


\section{Finding and Discussion}

This is the part that contains the discussion from the research. The research result which will be reviewed is the result of quantitative data that was processed with the WarpPLS program (Kock, 2014, 2013). Quantitative data processing which shows the corresponding model will explain a condition that we are looking for. A precise suitability model for a research object will give explanation and addition on analysing correlation factor of UXQ to IR.

\subsection{Outer Model Analysis}

By using WarpPLS, an outer analysis model is needed to see the validity and reliability question that was obtained from HEART Metrics and Intention to Reuse, a suitability requirement that is used for outer results from Convergent Validity and Discriminant Validity findings. If the value of convergent validity $>0.6$, then it can be stated that every variable has the correct indicator to form the variable. If the value of Composite reliability $>0.7$, Cronbach's alpha coefficients $>0.6$ and value of AVE $>0.5$, then it can be stated that the model has been tested for its variable reliability and its indicator (Amora, 2021; Kock, 2014, 2013).

Table 1

Measurement Result Convergent Validity

\begin{tabular}{|c|c|c|c|c|c|c|c|}
\hline & $\mathbf{H}$ & $\mathbf{E}$ & $\mathbf{A}$ & $\mathbf{R}$ & $\mathbf{T}$ & IR & $P$ value \\
\hline H1 & 0.774 & -0.244 & 0.080 & 0.210 & -0.021 & -0.010 & $<0.001$ \\
\hline H2 & 0.774 & 0.021 & 0.097 & 0.014 & 0.038 & -0.204 & $<0.001$ \\
\hline H3 & 0.709 & -0.268 & 0.181 & -0.062 & -0.354 & 0.296 & $<0.001$ \\
\hline H4 & 0.708 & 0.056 & 0.393 & -0.237 & -0.141 & 0.004 & $<0.001$ \\
\hline H5 & 0.681 & 0.056 & 0.334 & -0.144 & -0.158 & -0.017 & $<0.001$ \\
\hline H6 & 0.687 & 0.404 & -0.358 & -0.147 & -0.085 & 0.158 & $<0.001$ \\
\hline H7 & 0.720 & 0.110 & -0.365 & 0.011 & 0.176 & -0.111 & $<0.001$ \\
\hline H8 & 0.751 & 0.006 & -0.293 & 0.046 & 0.060 & -0.095 & $<0.001$ \\
\hline H9 & 0.762 & -0.190 & -0.091 & 0.190 & 0.037 & 0.071 & $<0.001$ \\
\hline H10 & 0.784 & -0.109 & 0.090 & 0.043 & -0.067 & 0.087 & $<0.001$ \\
\hline H11 & 0.757 & -0.132 & 0.105 & -0.068 & 0.121 & 0.076 & $<0.001$ \\
\hline H12 & 0.688 & 0.368 & -0.179 & 0.099 & 0.386 & -0.251 & $<0.001$ \\
\hline E1 & 0.054 & 0.814 & 0.253 & -0.052 & -0.429 & 0.275 & $<0.001$ \\
\hline E2 & 0.035 & 0.842 & -0.027 & 0.262 & -0.023 & -0.303 & $<0.001$ \\
\hline E3 & -0.050 & 0.840 & -0.030 & -0.264 & 0.077 & 0.164 & $<0.001$ \\
\hline E4 & -0.018 & 0.889 & -0.061 & -0.043 & 0.136 & -0.186 & $<0.001$ \\
\hline E5 & -0.019 & 0.819 & -0.126 & 0.099 & 0.223 & 0.072 & $<0.001$ \\
\hline A1 & 0.019 & -0.025 & 0.921 & -0.083 & -0.087 & 0.157 & $<0.001$ \\
\hline A2 & -0.019 & 0.025 & 0.921 & 0.083 & 0.087 & -0.157 & $<0.001$ \\
\hline R1 & -0.007 & 0.055 & 0.118 & 0.882 & -0.065 & -0.077 & $<0.001$ \\
\hline $\mathbf{R 2}$ & 0.040 & -0.075 & -0.039 & 0.919 & -0.033 & 0.072 & $<0.001$ \\
\hline $\mathbf{R 3}$ & -0.033 & 0.021 & -0.073 & 0.930 & 0.095 & 0.002 & $<0.001$ \\
\hline T1 & -0.035 & -0.040 & 0.258 & -0.033 & 0.771 & 0.077 & $<0.001$ \\
\hline T2 & 0.010 & 0.216 & -0.155 & 0.409 & 0.782 & -0.523 & $<0.001$ \\
\hline T3 & 0.128 & -0.139 & 0.104 & 0.001 & 0.755 & 0.106 & $<0.001$ \\
\hline T4 & -0.006 & 0.092 & -0.079 & 0.213 & 0.811 & -0.292 & $<0.001$ \\
\hline T5 & 0.111 & -0.140 & 0.111 & -0.426 & 0.693 & 0.343 & $<0.001$ \\
\hline T6 & 0.081 & 0.204 & -0.156 & 0.211 & 0.778 & -0.366 & $<0.001$ \\
\hline T7 & 0.124 & -0.102 & 0.204 & -0.421 & 0.703 & 0.401 & $<0.001$ \\
\hline T8 & 0.022 & 0.066 & -0.056 & 0.133 & 0.793 & -0.103 & $<0.001$ \\
\hline T9 & -0.125 & -0.046 & -0.062 & -0.180 & 0.775 & 0.266 & $<0.001$ \\
\hline T10 & -0.214 & 0.012 & -0.135 & -0.038 & 0.759 & 0.124 & $<0.001$ \\
\hline T11 & -0.090 & -0.187 & 0.007 & 0.034 & 0.657 & 0.081 & $<0.001$ \\
\hline IR1 & 0.018 & -0.155 & 0.037 & -0.189 & 0.127 & 0.876 & $<0.001$ \\
\hline IR2 & -0.087 & 0.093 & 0.022 & 0.275 & -0.082 & 0.883 & $<0.001$ \\
\hline IR3 & 0.069 & 0.061 & -0.058 & -0.087 & -0.044 & 0.885 & $<0.001$ \\
\hline
\end{tabular}

The result of convergent validity has corresponding value with its requirement that is with $\mathrm{P}$-value $<0.5$, while the value indicator instrument is $>0.7$. Then, the statements in this research considered valid for then move forward to next step testing, that is Cronbach's alpha coefficients observing, composite reliability, and Discriminant validity.

Table 2

Measurement Result Discriminate Validity

\begin{tabular}{lcccccc} 
& & \multicolumn{4}{c}{ Instrument Research } \\
\cline { 2 - 6 } Measurement Point & Happiness & Engagement & Adoption & Retention & Task Success & Intention Reuse \\
\hline Cronbach's alpha coefficients & 0.922 & 0.896 & 0.822 & 0.897 & 0.923 & 0.856 \\
Composite reliability & 0.933 & 0.924 & 0.918 & 0.936 & 0.935 \\
AVE & 0.734 & 0.841 & 0.921 & 0.911 & 0.754 \\
\hline
\end{tabular}


As stated before, to suffice reliability value as a whole and in every indicator, then it needs to observe Ca, Cr, and AVE. The discriminant validity value shows that value of $\mathrm{Ca}>0.6$, value of $\mathrm{Cr}>0.7$, and value of $\mathrm{AVE}>0.05$, it means, the reliability on question items is reliable, so the discriminant validity requirement on this research is sufficient.

\subsection{Inner Model Analysis}

Inner model analysis part is needed to observe the correlation of HEART Metrics to Intention to Reuse. This condition can be observed by Model Fit by considering the calculation of R-Square, Q-Square, and Goodness of Fit (GoF). The value on RSquare Contribution Ratio coefficient (RSCR) stated in 2 categories as "acceptable if $>=0.9$, ideally (equal mark) 1 ", and value of Q-Square is suggested $>0$, while for Tenenhaus Gof (GoF) stated in 3 categories as "small $>=0.1$, medium $>=0.25$, large $>=0.36 "$ (Kock, 2014, 2013).

Table 3

Measurement Result Model Fit

\begin{tabular}{lll}
\hline Measurement Point & Estimated Model & Justification \\
\hline R-Square & 1.000 & Ideally \\
Q-Square & 0.638 & Acceptable \\
GoF & 0.674 & Large \\
\hline
\end{tabular}

The result shows R-Square value as 1.000 , so it can be said the proposed research model correlation between HEART Metrics to Intention to Reuse can be interpreted well as 100\%, while Q-Square accepted value as 64\% from proposed structural model, large value of GoF indicates that observed model reliability is acceptable.

\subsection{Path Coefficient Analysis}

The results of data processing using Warp-PLS show the relationship between factors using the HEART Metrics conceptual approach model with Intention to Reuse related to the evaluation of Indonesian Tourism G2C measurements through the official website indonesia.travel. The P-Value value shows the significance of the correlation between variables if the P-value of $\mathrm{P}<0.05$, it is stated that the relationship between variables is significant (Kock, 2014, 2013).

\section{Table 4}

Measurement Path Coefficient Analysis

\begin{tabular}{llll}
\hline Correlation Between Variables & Path Coefficient & P-Value & Justification \\
\hline Happiness $\rightarrow$ Intention Reuse & 0.064 & 0.149 & Not Significant \\
Engagement $\rightarrow$ Intention Reuse & 0.102 & 0.049 & Significant \\
Adoption $\rightarrow$ Intention Reuse & 0.075 & 0.112 & Not Significant \\
Retention $\rightarrow$ Intention Reuse & 0.294 & $<0.001$ & Significant \\
Task Success $\rightarrow$ Intention Reuse & 0.392 & $<0.001$ & Significant \\
\hline
\end{tabular}

First, the point of view from a series of findings is in table 4, where the table presents the tested factors, namely Happiness, Engagement, Adoption, Retention, Task Success on Intention Reuse. From the findings obtained, the HEART Metrics framework does not affect all factors successfully on Intention Reuse, it is found that the relationship between Happiness and Adoption on Intention Reuse is not significant, while the other 3 factors, namely Engagement, Retention, Task Success, have an influence on Intention Reuse. This study provides other findings with some of its predecessors (Albert et al., 2008; Pratama et al., 2019; Rodden et al., 2010; Santosa, n.d.), The HEART Metric that transforms into a predictor is able to influence endogenously, this means that the proposed model variables can be used as an initial reference to evaluate user experience within the scope of Confirmatory factor analysis (CFA) and exploratory factor analysis (EFA) research.

Second, with the magnitude of the HEART dimension being a predictor, finally contributing to each factor that can be calculated empirically, Task Success path values of 40\%, Retention (30\%), and Engagement (10\%) respectively are the dominant factors to influence the Intention to Reuse. In its implementation, G2C services are considered successful when there is no or infrequent breakdown when operated by the user. This Indonesia.travel service is felt to have the ability to do that, it is not easy for interference or excessive advertising to occur. The task goes well when the expectations and performance are as expected by the user, meaning that the application of G2C Tourism services in Indonesia. travel is deemed to have performed in accordance with user expectations.

The retention factor has a positive influence on Intention Reuse, meaning that the application of Indonesia.travel is also perceived as an easy in finding, finding, storing, and executing an action, for example: looking for a tourist destination in Indonesia that is included in the top 5 national tourism categories and then ordering a tour package. to visit the tour. Significant impact Retention can provide experiences that support the process of knowledge tourism in Indonesia.

While the observations from the findings of Happiness and Adoption which have no effect on Intention Reuse while Engagement as a factor that affects Intention Reuse, various similar studies on HEART Metrics (Boy et al., 2015; Conlen et al., 2019; Hung \& Parsons, 2017; Illias \& Kokkinaki, 2015; Lalmas et al., 2014; Müller \& Sedley, 2014; Rodden et al., 2010) describes that Happiness and Engagement often have an interrelated relationship, but the findings in this study give different results, 
Happiness has no effect on Intention Reuse while Engagement can affect Intention Reuse. This finding provides a new contribution in involving HEART Metrics as a predictor as well as material to be re-examined in several case studies from e-gov to e-commerce.

Three, the purpose of making G2C digital services is one of them so that the information shared can be easily obtained by the public and expect the services to be provided repeatedly and continuously. In the ISSM study for Intention Reuse (Aldholay et al., 2018; Bernroider, 2008; DeLone \& McLean, 2004, 2003; Hsu et al., 2014; Lathif et al., n.d.; Petter et al., 2008; Suryanto et al., 2016, 2017) often use information quality, system quality, and service quality as predictor variables. but some questions from HEART Metrics can accommodate all three qualities in ISSM, if observed through the HEART Metrics Intention Reuse predictor G2C can be influenced by Task Success, Retention, and Engagement factors., the features in the service can be in accordance with the functionality and in accordance with the user's expectations so that in this case it creates a good relationship between the service provider, the user, and the repetition of using the service.

Meanwhile, other factors, namely Happiness, and Adoption have no effect on Intention Reuse. This phenomenon is possible because of the application conditions of users who want closer use of their expectations when operating tourism virtualization, adopting various technologies, and implementing them into G2C services, which will be more experienced and experienced, so that there is a sense of pleasure visiting via virtual and much further. closer, cheaper, more friendly, and can be used as expected.

Finally, In cases of user experience research that often involves an evaluation (Albert et al., 2008; Boy et al., 2015; Conlen et al., 2019; Finstad, 2010; Hung \& Parsons, 2017; Lalmas et al., 2014; Müller \& Sedley, 2014; Pratama et al., 2019; Santosa, n.d.; Tripathi, 2021) but there are still few researchers who explore the scope of this evaluation into pathway findings, thus providing a little fundamental, of course there are still many studies in this study that are expected to be used as ongoing research that explores HEART metrics as predictors.

\section{Conclusion and Suggested Future Research}

Based on the results of the discussions and discussions that have been presented, it is concluded that the HEART Metrics framework can be a predictor of the relationship between changes in emotions or feelings from user experience, this research model can explain $67 \%$ of these phenomena, intention to reuse online tourism G2C services based on user experience. Observing the findings of this study, it is recommended that services based on Governance to Customer (G2C) provide a good user experience with a priority scale that is in accordance with the characteristics of the service.

Acknowledgment

Thank you to the Universitas Pembangunan Nasional "Veteran" Jawa Timur for the moral and material support so that this paper can be published, thanks also to Universitas Atma Jaya Yogyakarta for being involved in the process of making this paper. A very special thanks to the Lab. Management Information System, Department of Information Systems.

\section{References}

10 Usability Heuristics for User Interface Design. (2021). https://www.nngroup.com/articles/ten-usability-heuristics/

Albert, W., Tullis, T., \& Albert, W. (2008). Measuring the User Experience. In Measuring the User Experience. Elsevier Inc. https://doi.org/10.1016/B978-0-12-373558-4.X0001-5

Aldholay, A., Isaac, O., Abdullah, Z., Abdulsalam, R., \& Al-Shibami, A. H. (2018). An extension of Delone and McLean IS success model with self-efficacy: Online learning usage in Yemen. International Journal of Information and Learning Technology, 35(4), 285-304. https://doi.org/10.1108/IJILT-11-2017-0116

Amora, J. T. (2021). Convergent validity assessment in PLS-SEM : A loadings-driven approach. 2(June), 1-6.

Bernroider, E. W. N. (2008). IT governance for enterprise resource planning supported by the DeLone-McLean model of information systems success. Information and Management, 45(5), 257-269. https://doi.org/10.1016/j.im.2007.11.004

Boy, J., Detienne, F., \& Fekete, J. D. (2015). Storytelling in information visualizations: Does it engage users to explore data? Conference on Human Factors in Computing Systems - Proceedings, 2015-April, 1449-1458. https://doi.org/10.1145/2702123.2702452

Conlen, M., Kale, A., \& Heer, J. (2019). Capture \& analysis of active reading behaviors for interactive articles on the web. Computer Graphics Forum, 38(3), 687-698. https://doi.org/10.1111/cgf.13720

DeLone, W. H., \& McLean, E. R. (2004). Measuring e-commerce success: Applying the DeLone and McLean Information Systems Success Model. International Journal of Electronic Commerce, 9(1), 31-47. https://doi.org/10.1080/10864415.2004.11044317

DeLone, W. H., \& McLean, E. R. (2003). The DeLone and McLean model of information systems success: A ten-year update. Journal of Management Information Systems, 19(4), 9-30. https://doi.org/10.1080/07421222.2003.11045748

Finstad, K. (2010). The usability metric for user experience. Interacting with Computers, 22(5), $323-327$. https://doi.org/10.1016/j.intcom.2010.04.004

Hameed, H. (2017). Quantitative and qualitative research methods: Considerations and issues in qualitative research PV Power Systems View project Private Tutoring View project. June. https://doi.org/10.13140/RG.2.2.36026.82883 
Hsu, M. H., Chang, C. M., Chu, K. K., \& Lee, Y. J. (2014). Determinants of repurchase intention in online group-buying: The perspectives of DeLone \& McLean is success model and trust. Computers in Human Behavior, 36, $234-245$. https://doi.org/10.1016/j.chb.2014.03.065

Hung, Y.-H., \& Parsons, P. (2017). Assessing User Engagement in Information Visualization. Proceedings of the 2017 CHI Conference Extended Abstracts on Human Factors in Computing Systems. http://dx.doi.org/10.1145/3027063.3053113

Illias, F., \& Kokkinaki, A. (2015). (PDF) On the Evaluation of OLEs Using the HEART Framework Evaluation of Online Environments.

Proceedings

Ascilite. https://www.researchgate.net/publication/287310811_On_the_Evaluation_of_OLEs_Using_the_HEART_Framework_E valuation_of_Online_Learning_Environments

Kock. (2014). Ned Kock - Collaborative for International Technology Studies. Advanced Mediating Effects Tests, MultiGroup Analyses, and Measurement Model Assessments in PLS-Based SEM. International Journal of e-Collaboration, 10(3), 1-13., 94.

Kock, N. (2013). WarpPLS User Manual 4.0.94.

Lachner, F., Fincke, F., \& Butz, A. (2017). UX Metrics: Deriving Country-Specific Usage Patterns of a Website Plug-In from Web Analytics. Lecture Notes in Computer Science (Including Subseries Lecture Notes in Artificial Intelligence and Lecture Notes in Bioinformatics), 10515 LNCS, 142-159. https://doi.org/10.1007/978-3-319-67687-6_11

Lalmas, M., O’Brien, H., \& Yom-Tov, E. (2014). Measuring User Engagement. Synthesis Lectures on Information Concepts, Retrieval, and Services, 6(4), 1-132. https://doi.org/10.2200/s00605ed1v01y201410icr038

Lathif, T., Suryanto, M., Setyohadi, D. B., \& Fauzi, A. (n.d.). Self-Efficacy a Critical Factor of Information System: An Investigation using DeLone McLean.

Lee, Y., \& Kim, Y. (2018). Structural Relationships among Tourism Information, Payment Service, Satisfaction, and Intention to Reuse: Focused on the Ctrip APP in China. 9(2), 123-136.

Min Tun, P. (2020). Factors Influencing Intention to Reuse Mobile Banking Services for the Private Banking Sector in Myanmar Mobile Financial Services in Myanmar View project Factors Influencing Intention to Reuse Mobile Banking Services for the Private Banking Sector in Mya. Asean Journal of Management \& Innovation, August. https://doi.org/10.14456/ajmi.2020.5

Müller, H., \& Sedley, A. (2014). HaTS: Large-scale In-product Measurement of User Attitudes \& Experiences with Happiness Tracking Surveys. https://doi.org/10.1145/2686612.2686656

Müller, H., Sedley, A., \& Ferrall-Nunge, E. (2014). Survey research in HCI. In Ways of Knowing in HCI (pp. 229-266). Springer New York. https://doi.org/10.1007/978-1-4939-0378-8_10

Natalia, Bianca, S., \& Pradipta, I. A. (2019). Analysis User Acceptance of Wonderful Indonesia Application Using Technology Acceptance Model (case study: Indonesian Ministry of Tourism). Proceedings of 2019 International Conference on Information Management and Technology, ICIMTech 2019, 234-238. https://doi.org/10.1109/ICIMTech.2019.8843785

Nugraha, D. Y., \& Sudirman, I. D. (2019). Does the Quality of Indonesian Tourism Website Influence Foreign Tourist Decision to Visit Indonesia? International Journal of Recent Technology and Engineering, 8(4), 5719-5724. https://doi.org/10.35940/ijrte.d8468.118419

Park, E. (2019). The role of satisfaction on customer reuse to airline services: An application of Big Data approaches. Journal of Retailing and Consumer Services, 47, 370-374. https://doi.org/10.1016/J.JRETCONSER.2019.01.004

Petter, S., Delone, W., \& Mclean, E. (2008). Measuring information systems success: models, dimensions, measures, and interrelationships. European Journal of Information Systems, 17, 236-263. https://doi.org/10.1057/ejis.2008.15

Pratama, A. V., Lestari, A. D., \& Aini, Q. (2019). Analisis User Experience Aplikasi Academic Information System (Ais) Mobile Untuk User-Centered Metrics Menggunakan Heart Framework. Sistemasi, 8(3), 405. https://doi.org/10.32520/stmsi.v8i3.527

Rodden, K., Hutchinson, H., \& Fu, X. (2010). Measuring the User Experience on a Large Scale: User-Centered Metrics for Web Applications.

Rudenko, S., \& P. Tedjakusuma, A. (2018). Wonderful Indonesiaq country marketing campaign - how visible Indonesia as a tourism destination for Europeans. 178-181. https://doi.org/10.2991/insyma-18.2018.44

Santosa, P. I. (n.d.). MEASURING USER EXPERIENCE IN AN ONLINE STORE USING PULSE AND HEART METRICS | Jurnal Ilmiah Kursor. Retrieved June 24, 2021, from https://kursorjournal.org/index.php/kursor/article/view/40

Suryanto, T. L. M., Setyohadi, D. B., \& Faroqi, A. (2016). Analysis of the effect of information system quality to intention to reuse of employee management information system (Simpeg) based on information systems success model. MATEC Web of Conferences, 58. https://doi.org/10.1051/matecconf/20165803001

Suryanto, T. L. M., Setyohadi, D. B., \& Wibowo, N. C. (2017). Empirical investigation on factors related to individual of impact performance information system. International Conference on Electrical Engineering, Computer Science and Informatics (EECSI), 2017-December. https://doi.org/10.1109/EECSI.2017.8239123

The Official Website of Indonesia Tourism - Indonesia Travel. (2021). https://www.indonesia.travel/id/id/home

Tripathi, R. (2021). Use of Web Analytics and Social Listening to Attract International Students. In Global Perspectives on Recruiting International Students: Challenges and Opportunities (pp. 65-79). Emerald Publishing Limited. https://doi.org/10.1108/978-1-83982-518-720211004

Yunus, U., Anindito, Tanuar, E., \& Maryani. (2018). Usability testing of indonesia tourism promotion website. Journal of Physics: Conference Series, 978(1), 12007. https://doi.org/10.1088/1742-6596/978/1/012007 


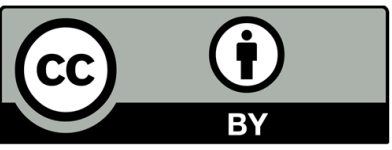

(C) 2021 by the authors; licensee Growing Science, Canada. This is an open access article distributed under the terms and conditions of the Creative Commons Attribution (CC-BY) license (http://creativecommons.org/licenses/by/4.0/). 